\title{
The Separation of Total Plasma Insulin from Binding Proteins Using Gel Filtration: Its Application to the Measurement of Rate of Insulin Disappearance
}

\author{
Margaret J. Pearson and F.I.R. Martin \\ Departments of Biochemistry and Endocrinology, The Royal Melbourne Hospital, Victoria, Australia
}

Received: November 22, 1969

\begin{abstract}
Summary. Insulin levels in insulin-treated diabetics were measured by a simple technique using gel filtration on Sephadex G-50 at low $\mathrm{pH}$ to separate plasma insulin from binding proteins. This method was used to measure the rate of disappearance of intravenously injected insulin in the plasma of diabetics with high levels of antibodies to heterologous insulin. - The half-time of disappearance of insulin was found to be closely related to insulin antibody titre, but was not related to the acute hypoglycaemic effect of the injected insulin.
\end{abstract}

Utilisation d'une technique de filtration pour séparer l'insuline plasmatique totale des protéines auxquelles elle est liée: son application à la mesure du taux de disparition de l'insuline

Résumé. L'insulinémie chez les diabétiques traités par l'insuline a été mesurée par une technique simple utilisant le passage sur une colonne de Sephadex, à un $\mathrm{pH}$ bas, pour séparer l'insuline plasmatique des protéines auxquelles elle est fixée. Cette méthode a été employée pour mesurer le taux de disparition de l'insuline injectée par voie intraveineuse chez des diabétiques ayant des anticorps anti-insuline hétérologue à des taux très élevés. -
La demi-vie de l'insuline ainsi déterminée est en relation étroite avec le taux d'anticorps antiinsuline mais est sans rapport avec l'effet hypoglycémique de l'insuline injectée.

Die Trennung von Gesamtplasma-Insulin und Bindungs-Eiweiß durch Gel-Filtration: Ihre Anwendung auf die Messung der Insulinschwundrate

Zusammenfassung. Die Insulinspiegel bei insulinbehandelten Diabetikern wurden mit Hilfe einer einfachen Methode unter Verwendung der Gel-Filtration auf SephadexG-50 bei niedrigen $\mathrm{pH}$ zur Trennung des Plasmainsulins und der Bindungs-Eiweißkörper gemessen. Das Verfahren diente zur Messung der Schwundrate von intravenös injiziertem Insulin aus dem Plasma von Diabetikern mit hohen Spiegeln von Antikörpern gegenüber heterologem Insulin. - Die Halbwertszeit für das Verschwinden des Insulins stand dabei in engem Zusammenhang zu dem Insulin-Antikörper-Titer, wies jedoch keine Beziehungen zu dem akuten blutzuckersenkendem Effect des injizierten Insulins auf.

Key-words: Sephadex, insulin, antibody, plasma insulin, disappearance.

\section{Introduction}

The presence of insulin-binding antibodies invalidates the measurement of plasma insulin by immunoassay. Such antibodies are the usual consequence of the treatment of diabetics with insulin. Several authors have used acid ethanol to separate the insulin-antibody complex and extract insulin from plasma (Baird and Bornstein 1957, Grodsky and Forsham 1960, Davoren 1962 and Heding and Nielson 1967), but it has been suggested (Gjedde 1968) that these methods produce denatured proteins with insulin-like properties in the denatured state. In our hands, acid ethanol methods were found to be unsatisfactory, since the end product was frequently in the form of a suspension which was unsuitable for immuno-assay and which made reproducible results difficult to obtain. It has recently been reported that acid ethanol is inferior to salt ethanol as an extracting agent (Ide, Kuzuya, Kajinuma, Kanazawa, and Kosaka 1969).

An alternative simple technique in which the components of the insulin-antibody complex are separated on Sephadex at low $\mathrm{pH}$ prior to immuno-assay has been used in our laboratory. This method is based on the observation that the insulin-antibody complex is split at $\mathrm{pH}$ less than 5 (Grodsky, Peng, and Forsham 1959). The method has been used to measure total in- sulin in plasma, and to investigate the disappearance rate of injected insulin in patients with high levels of insulin antibodies.

\section{Materials and Methods}

Sephadex G-50 and G-100 were obtained from Pharmacia, Uppsala, Sweden. The radioactive insulin used was either ${ }^{131} \mathrm{I}$-insulin, specific activity $280 \mu \mathrm{Ci} / \mu \mathrm{g}$, obtained from Abbott Laboratories, Illinois, U.S.A. or ${ }^{125} \mathrm{I}$ insulin, specific activity approximately $150 \mu \mathrm{Ci} / \mu \mathrm{g}$, prepared in our laboratory by the method of Hunter and Greenwood (1962) using ${ }^{125} \mathrm{I}$ obtained from Amersham, U.K., and Lilly pork insulin, Lot No. PJ5589. This pork insulin was also used as a standard throughout.

Preliminary experiments were performed to determine the efficiency of separation of insulin from antibody. Radioactive insulin was incubated overnight at $4^{\circ} \mathrm{C}$ with normal plasma or plasma containing antibodies to heterologous insulin ("binding plasma"). These were fractionated on columns of either Sephadex G-50 (14 cm length by $1.5 \mathrm{~cm}$ diameter) or G-100 (23 cm length by $1.5 \mathrm{~cm}$ diameter) using $0.9 \% \mathrm{NaCl}$ containing $0.02 \%$ sodium azide, adjusted to $\mathrm{pH} 7$ or $\mathrm{pH} 3$ with $6 \mathrm{M} \mathrm{HCl}$, as eluant. Fractions were collected into tubes coated with human serum albumin (Cohn Frac- 
tion V, C.S.L. Melbourne) and counted in a NuclearChicago Automatic Gamma Counter. Fractions taken from the excluded and included peaks (i.e. fractions 3 and 13, Fig. 1) were adjusted to $\mathrm{pH} 7$ with $0.1 \mathrm{M} \mathrm{NaOH}$ and incubated at room temperature for two hours. They were then subjected to chromato-electrophoresis in Veronal buffer at pH 8.5 (Berson, Yalow, Bauman, Rothschild, and Newerly 1956).
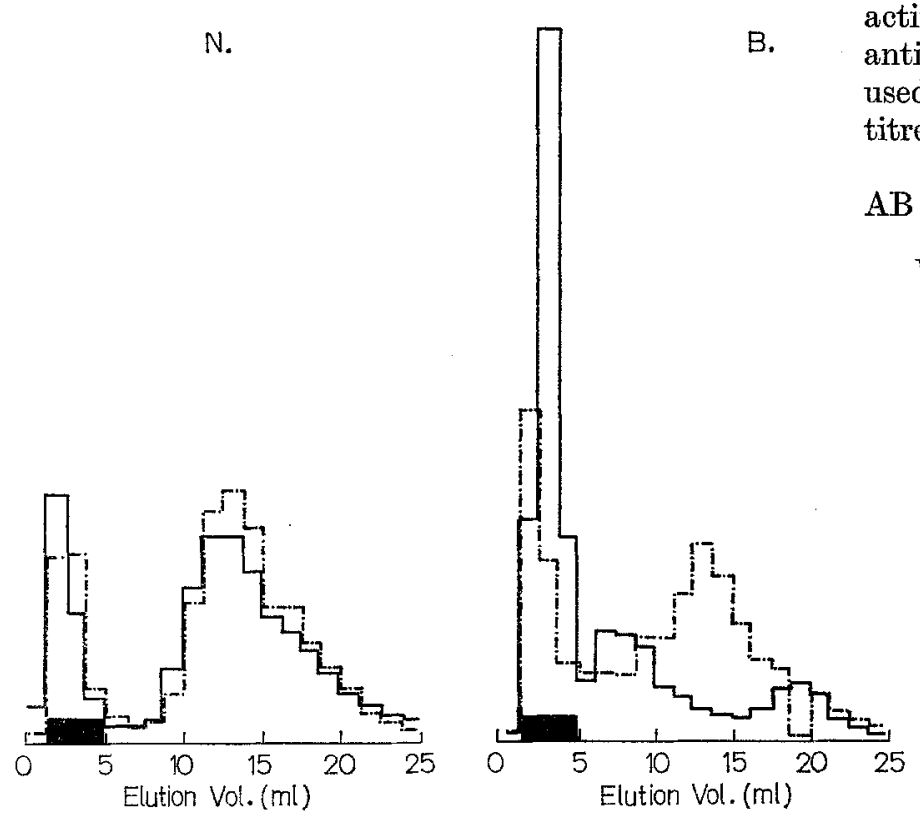

Fig. 1. The results of the distribution of radioactivity obtained when ${ }^{125} \mathrm{I}$ insulin was incubated with normal (N) or binding (B) plasma then filtered on Spehadex G-50 at $\mathrm{pH} 3$ or $\mathrm{pH} 7$

There was no significant difference in the resolution of added ${ }^{131} I$ insulin obtained using G-100 or G-50 and subsequently G-50 columns were used exclusively.

In order to determine total plasma insulin, 0.2 $0.5 \mathrm{ml}$ of plasma was filtered on G-50 Sephadex. The excluded protein fractions as determined by the biuret test were discarded. The fractions containing insulin were collected as above, pooled, and stored at $-10^{\circ} \mathrm{C}$. Insulin was measured in triplicate by a modification (Pearson, Fullerton, Martin and Melick 1968) of the coated charcoal immuno-assay of Herbert, Lau, Gottleib and Bleicher (1965).

Normal subjects, diabetics treated without insulin and diabetic patients with antibodies to heterologous insulin were studied to determine the rate of disappearance of injected insulin in relation to the fall in blood glucose. 0.1 units per $\mathrm{kg}$ body weight of glucagonfree insulin (Eli Lilly Australia, Ltd.), was given intravenously after an overnight fast, and venous blood samples were taken from the opposite arm at $5 \mathrm{~min}$ intervals, for $30 \mathrm{~min}$ for the estimation of blood glucose and total plasma insulin. Plasma insulin values were plotted on semi-logarithmic paper and the half-time of the disappearance rates determined from the line of best fit. The half-time of disappearance of blood glucose was determined similarly, and insulin sensitivity was expressed as a rate constant, $k$, where $k=$ $\frac{0.693}{\mathrm{t}^{\frac{x}{2}} \text { blood glucose }}$ (Martin, Stocks and Pearson, 1967).

Each patient was also tested for antibodies to heterologous insulin. $0.1 \mathrm{ml}$ of a fasting plasma sample was incubated with a standard amount $(8 \mathrm{uU})$ of radioactive insulin for $48 \mathrm{~h}$ at $4^{\circ} \mathrm{C}$, then the remaining free antigen adsorbed onto dextran-coated charcoal as used in the immuno-assay system. The "antibody titre" was determined from the formula:

$$
\mathrm{AB} \text { titre }=\frac{\mathrm{SC}_{\text {test plasma }}-\mathrm{SC}_{\text {antibody free plasma }}}{\mathrm{TC}} \times 100
$$

Where $\mathrm{SC}=$ counts remaining in the supernatant after treatment with charcoal.

$\mathrm{TC}=$ total counts added to the incubation mixture.

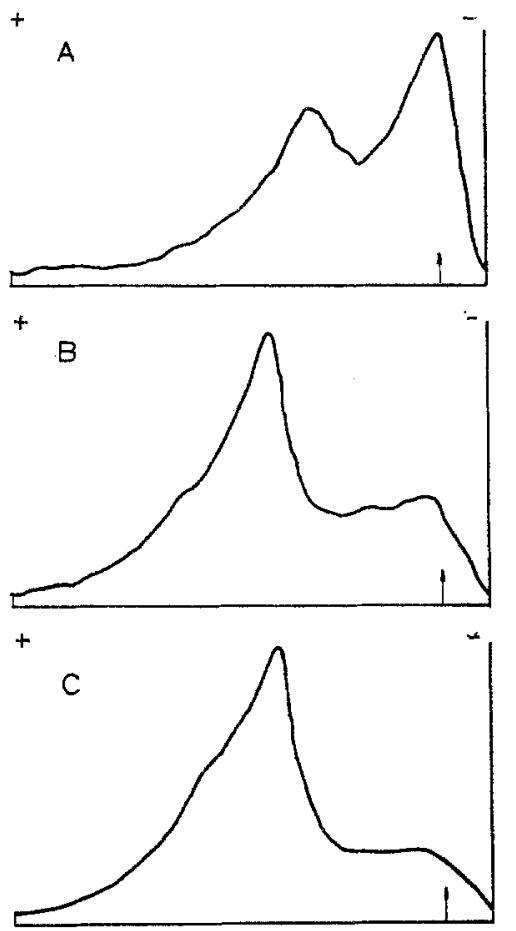

Fig. 2. Chromato-electrophoresis of the excluded peak obtained after radioactive insulin and plasma were incubated and fractionated;

A. Binding plasma, eluted at $\mathrm{pH} 7$.

B. Binding plasma, eluted at $\mathrm{pH}$.

C. Normal plasma, eluted at $\mathrm{pH} 3$.

Insulin remains at the origin (arrowed) under these conditions, whereas antibody-bound insulin and damaged pepides move towards the anode

\section{Results}

The results of the distribtion of radioactivity obtained when ${ }^{125} \mathrm{I}$ insulin was incubated with normal and binding plasma, then fractionated at $\mathrm{pH} 7$ and $\mathrm{pH} 3$, are shown in Fig. 1. Quantitative recoveries were obtained. 
In normal plasma, radioactivity bound non-specifically by large proteins was clearly separated from free ${ }^{125} \mathrm{~T}$ insulin, and the percentage of the radioactivity in the excluded peak did not increase at $\mathrm{pH} 3$, indicating that

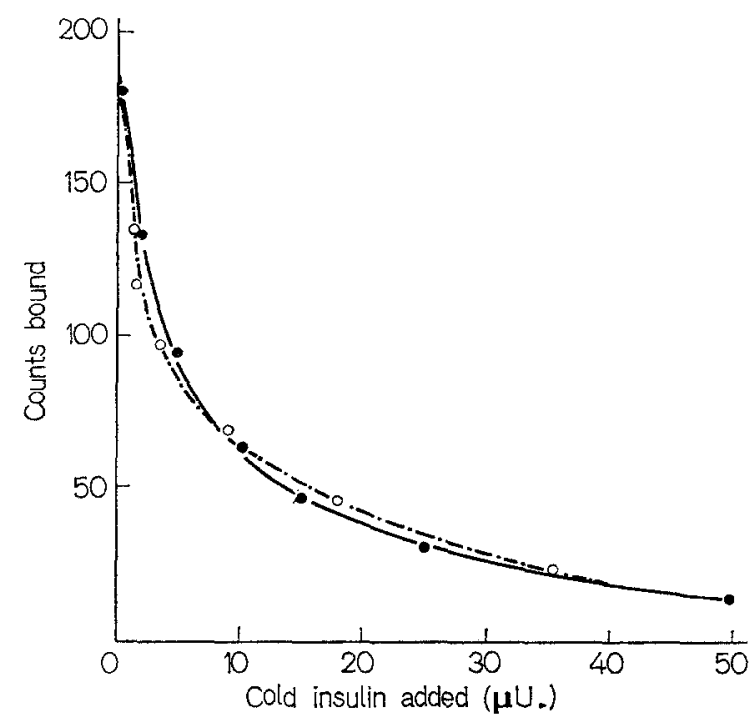

Fig. 3. Comparison of immuno-reactivity of insulin eluted from the column (broken line) with standard pork insulin (solid line) ahead of the free insulin, whereas at $\mathrm{pH} 3$ the distribution of radioactivity corresponded to the normal elution pattern.

The adequacy of separation was confirmed by chromato-electrophoresis of fractions taken from the columns, which showed that although insulin was present in the excluded peak of the binding plasma at $\mathrm{pH}$ 7 , this became negligible at $\mathrm{pH} \mathrm{3,} \mathrm{similar} \mathrm{to} \mathrm{normal}$ plasma (Fig. 2). Chromato-electrophoresis of the included peak confirmed that the radioactivity of the included peak was due to "free" radioactive insulin.

The position of the peak of immuno-assayable insulin after gel filtration at pH 3 of a binding plasma, and a normal plasma containing added standard pork insulin, was identical with the position of the "free" radioactive insulin peak obtained in preliminary studies. Estimation of the partition coefficient $K_{a v}$ for the insulin peak corresponded to a value for a globular protein of molecular weight $7000 \pm 1000$, and when immuno-assay of serial dilutions of the extracted insulin were compared on two occasions with standard pork insulin, the dilution curves appeared identical (Fig. 3).

The recovery of the method for immuno-reactive insulin (I.R.I.) was assessed by adding between 60 and 1400 micro units of standard pork insulin to plasma obtained from 10 normal people, and assaying the

Table 1. Table of Results

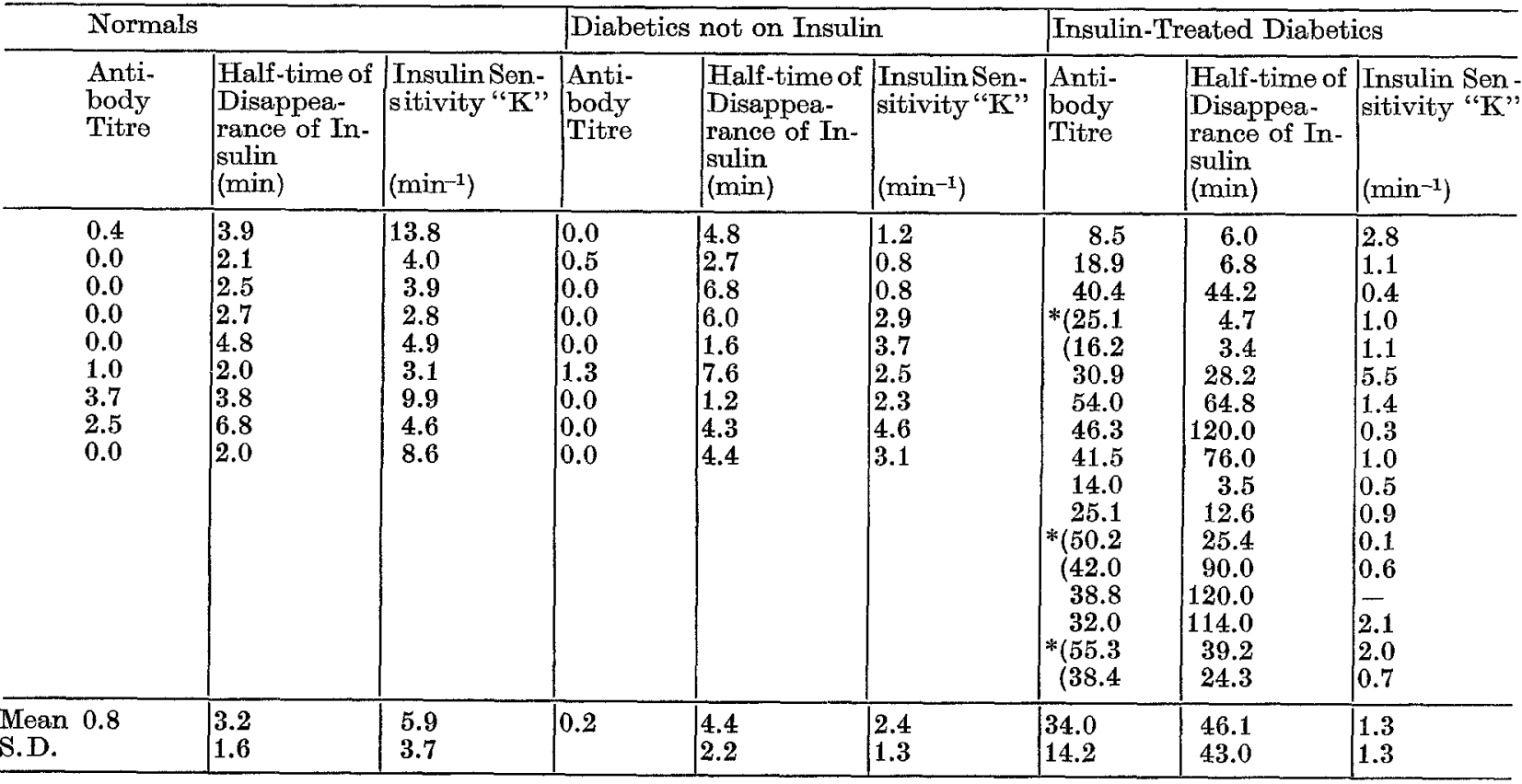

* Repeat Estimations.

1 The Antibody Titre represents the percentage of $80 \mu \mathrm{U}$ of ${ }^{125} \mathrm{I}$-insulin bound per millilitre of serum.

there was no association of insulin under these conditions. In contrast, in binding plasma, there was a much larger excluded fraction at $\mathrm{pH} 7$, indicating that ${ }^{125} \mathrm{I}$ insulin had been bound by antibody and was eluted samples before and after fractionation. The average recovery was $120 \%$. However, this method was not applicable to binding plasmas, so a further recovery experiment was performed in which six normal and six 
binding plasmas were fractionated before and after the addition of between 60 and 1250 micro units pork insulin, and the eluates compared. The average recovery for the normals was $79 \%$ (range $58 \%-126 \%$ ) and for the binding plasmas $99 \%$ (range $74 \%-131 \%$ ).

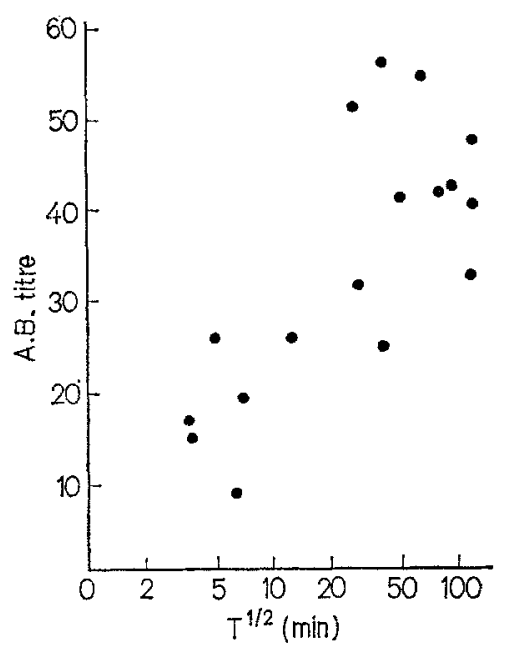

Fig. 4. The half-time of rate of disappearance on insulin compared with the antibody titre of the plasma. (semi. logarithmic scale)

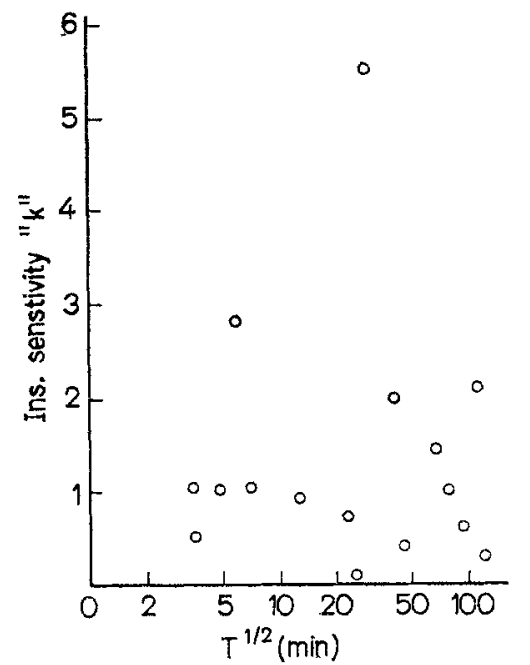

Fig. 5. The half-time of rate of disappearance of insulin compared with the insulin sensitivity " $K$ ". (semilogarithmic scale)

Levels of plasma insulin found in six fasting insulintreated diabetics were very high, being in the range $700-6000 \mu \mathrm{U} / \mathrm{ml}$. By comparison, fasting levels in non-insulin treated diabeties were less than the limits of sensitivity of the procedure - i.e. less than $40 \mu \mathrm{U} / \mathrm{ml}$. However, preliminary experiments using a "Diaflow" Ultrafiltration Membrane to concentrate the effuent from the column indicate that levels as low as $10 \mu \mathrm{U} / \mathrm{ml}$ can be detected.

The half-time disappearance rates of total plasma insulin in 14 insulin-treated diabetic patients, 9 non- insulin-treated diabetics and 10 normal subjects are shown in Table 1. The values obtained for normal subjects and non-insulin-treated diabetics were not significantly different (means 3.2 and 4.4 respectively), and were similar to those we have previously reported for insulin disappearance rates in untreated plasma (Martin et al. 1967). There was no significant difference in values for the half-time disappearance rate obtained in 20 patients when plasma was assayed before and after fractionation.

In the insulin-treated diabetics the half-time of disappearance of injected insulin varied widely from 3 minutes to $120 \mathrm{~min}$, mean $46.1 \mathrm{~min}$. In this group of 14 patients, 3 of whom were studied twice, there was a significant positive correlation between insulin disappearance rate and the estimated antibody titre $(r=$ $0.56, p<0.02$, Table 1 and Fig. 4). However, there was no relation between acute insulin sensitivity and either the rate of disappearance of insulin from plasma or the antibody titre $(r=0.10$ and $r=0.18$ respectively, Table 1 and Fig. 5).

In addition, the acute hypoglycaemic effect of insulin appeared to be quite unrelated to insulin disappearance rate in both the normal subjects and diabetics without antibodies to heterologous insulin as has been previously reported (Stimmler, 1967, Martin et al. 1967).

\section{Discussion}

A simple method of separating the total plasma immuno-reactive insulin from endogenous antibodies is described which permits the subsequent immunoassay of insulin levels in diabetics who have circulating antibodies from treatment with heterologous insulin. The procedure is rapid and technically easy, yet gives adequate sensitivity and recoveries while maintaining the immunological integrity of the hormone.

In this study no evidence of the presence of significant amounts of Pro-insulin was obtained from either the estimation of molecular weight of the insulin peak (Chance, Ellis and Bromer 1968) or the immunological comparison of the peak with standard pork insulin (Steiner, Hallund, Rubenstein, Cho, and Bayliss 1968). In view of the conditions used this was not surprising as Pro-insulin represents less than $20 \%$ of the total plasma I.R.I. in peripheral blood (Goldsmith, Yalow, and Berson 1969).

The amount of total plasma insulin present in the circulation of insulin-treated diabetics as estimated by the present technique agrees with levels reported by Heding and Nielson (1967) who used an alcohol precipitation method. Karam, Levin, Lecharny, Grodsky, and Forsham (1969) extracted total insulin from the plasma of 18 insulin-treated diabetics with an acid ethanol technique. Their range in 4 insulin-resistant diabetics was $8000-12000 \mu \mathrm{U} / \mathrm{ml}$ and 14 non-resistant patients with low anti-insulin titres had levels of $15-$ $3000 \mu \mathrm{U} / \mathrm{ml}$ of total extractable insulin. 
A close relation was found between the estimated titre of insulin antibodies and the insulin disappearance rate. In contrast there appeared to be no correlation between either insulin disappearance rate or antibody titre and the acute hypoglycaemic effect of insulin. Previously Martin and Stocks (1967) had reported that there was a barely significant degree of correlation between the acute hypoglycaemic potency of insulin and the disappearance rate of injected ${ }^{131}$ I-insulin in diabeties treated with insulin for many years. It is likely that such estimates using ${ }^{131}$ I-insulin are not reliable as it is frequently impure, there is evidence that the biological potency is reduced by even small degrees of iodination, (Arquilla, Ooms and Mercola 1968) and chromato-electrophoresis may not separate partially degraded peptides from insulin. In addition, the half time of disappearance of I.R.I. in normals and non-insulin treated diabetics has been shown to be shorter than for ${ }^{131} \mathrm{I}$-insulin (Ørskov and Christensen 1966, Stimmler 1967, McAdams, Knox, Wileox and Jensen 1967).

It is possible that the estimated disappearance rate of total insulin in the plasma of diabetics with insulin antibodies may not reflect actual changes in free circulating insulin arising from the variable release of insulin initially bound to antibody. Despite its limitations, the evidence from ${ }^{131} I$-insulin studies suggests that the degree of antibody binding of ${ }^{131}$ I-insulin five minutes and sixty minutes after injection is constant, and that the half-time of disappearance of ${ }^{131} I$-insulin is similar whether the "total" or "free" insulin is measured (Martin and Stocks 1967).

In view of the lack of a close relation between insulin disappearance rate and blood glucose fall, it would seem possible that only a small portion of injected insulin at a dose of $0.1 \mathrm{U} / \mathrm{kg}$ is responsible for the acute hypoglycaemic effect produced. The respective roles of the liver and peripheral tissues in determining acute insulin sensitivity in diabeties receiving insulin has been inadequately studied to date.

Acknowledgements: We are grateful to Dr. C.W. Baird and the Department of Biochemistry, Royal Melbourne Hospital, for the blood glucose estimations, and to the Department of Nuclear Medicine of the Royal Melbourne Hospital for isotopic measurement.

This work was supported in part by a grant from the National Health and Medical Research Council of Australia.

\section{References}

Arquilla, E.R., Ooms, H., Mercola, K.: Immunological and Biological Properties of Iodo-insulin labelled with one or less atoms of Iodine. J. clin. Invest. 47, 474-487 (1968).

Baird, C.W., Bormstein, J.: Plasma Insulin and Insulin Resistance. Lancet 1957 I, 1111 1113.
Berson, S.A., Yalow, R.S., Bauman, A., Rothschild, M. A., Newerly, K.: Insulin I131 Metabolism in Human Subjects: Demonstration of Insulin Binding Globulin in the Circulation of Insulin Treated Subjects. J. clin. Invest. 35, 170-190 (1956).

Chance, R.E., Ellis, R.M., Bromer, W.W.: Porcine Proinsulin: Characterization and Amino Acid Sequence. Science 161, 165-167 (1968).

Davoren, P.R.: The isolation of Insulin from a Single Cat Pancreas. Biochem. Biophys. Acta. 63, 150-153 (1962).

Gjedde, F.: Studies of the Insulin-like Activity of Serum. Acta endocr. 57, 478-504 (1968).

Grodsky, G.M., Forsham, P.H.: An Immunochemical Assay of Total Extractable Insulin in Man. J. clin. Invest. 39, 1070-1079 (1960).

- Peng, C.T., Forsham, P.H. : Effect of Modification of Insulin on Specific Binding in Insulin-Resistant Sera. Arch. Biochem. Biophys. 81, 264-272 (1959).

Goldsmith, S.T., Yalow, R. S., Berson, S.A.: Significance of Human Plasma Insulin Sephadex Fractions. Diabetes $18,834-839(1969)$.

Heding, L.G., Nielson, A.V.: Determination of Free and Antibody-bound I.R.I. in Serum From Insulin Treated. Diabetic Patients. Excerpta. Medica., International Congress Series 140, 114 (1967).

Herbert, V., Lau, K., Gottleib, C.W., Bleicher, S.I.: Coated Charcoal Immunoassay of Insulin. J. elin. Endocr. 25, 1375-1384 (1965).

Hunter, W.M., Greenwood, F.C.: Preparation of Iodine Labelled Human Growth Hormone of High Specific Activity. Nature (Lond.). 194, 495-496 (1962).

Ide, T., Kuzuya, T., Kajinuma, H., Kanazawa, Y., Kosaka, K.: Insulin-like Activity by Fat Pad Assay and Immunoreactive Insulin. Diabetes 18, 65-74 (1969).

Karam, J.H., Levin, S.R., Lecharny, B., Grodsky, G.M., Forsham, P.H.: Circulating Insulin Levels in InsulinTreated Diabetics. Diabetes 18, 361-362 (1969).

Martin, F.I.R., Stocks, A.E.: Insulin Sensitivity and $\mathrm{I}^{131}$ Insulin Metabolism in Juvenile-Type Diabetics. Aust. Ann. Med. 16, 289-296 (1967).

- - Pearson, M.J. . Significance of Disappearance Rate of Injected Insulin. Lancet 1967 I, 619-620.

Mc Adams, G.B., Knox, K.R., Wilcox, D. S., Jensen, R.: The Initial Rapid-Phase Disappearance of Intravenous Radio-Insulin in Diabetes. J. nuc. Med. 8, 173-178 (1967).

Ørskov, H., Christensen, N.J.: Disappearance-Rate of Exogenous Human Insulin. Lancet 1966 II, 701.

Pearson, M.J., Fullerton, M.J., Martin, F.I.R., Melick, R.: An Assessment of the Charcoal Immunoassay of Insulin. Proc. Aust. Ass. clin. Biochem. 1, 315--319 (1968).

Steiner, D.F., Hallund, O., Rubenstein, A., Cho, S., Bayliss, C.: Isolation and Properties of Pro-Insulin, Intermediate Forms and Other Minor Components from Crystalline Bovine Insulin. Diabetes 17, 725_-736 (1968).

Stimmler, L.: Disappearance of Immunoraactive Insulin in Normals and Adult-Onset Diabetic Subjects. Diabetes 16, 652-655 (1967).
M. J. Pearson
Depts. of Biochemistry
and Endocrinology
The Royal Melbourne Hospital
Victoria, Australia 